\title{
Hol van a normális és a kóros vérnyomás közötti határ, és mi a terápiás cél a cardiovascularis és a renalis betegségekben?
}

\author{
Kékes Ede dr. ${ }^{1}$ - Nagy Judit dr. $^{2}$ - Vályi Péter dr..$^{3,4,5}$ \\ ${ }^{1}$ Pécsi Tudományegyetem, Általános Orvostudományi Kar, Klinikai Központ, \\ I. Belgyógyászati Klinika, Kardiológiai és Angiológiai Tanszék, Pécs \\ ${ }_{2}^{2}$ Pécsi Tudományegyetem, Általános Orvostudományi Kar, \\ II. Belgyógyászati Klinika, Nephrológiai, Diabetológiai Centrum, Pécs \\ ${ }^{3}$ Magyar Hypertonia Társaság, Budapest \\ ${ }^{4}$ VALYTERÁPIA Egészségügyi és Szolgáltató Bt., Győr \\ ${ }^{5}$ Érgondnok Rendelőház, Sopron
}

\begin{abstract}
Az irodalmi adatok arra utalnak, hogy a systolés vérnyomás értékének emelkedése már 110-115 Hgmm-től együtt jár az atherosclerosissal összefüggő elváltozások kialakulásával is és ezzel együtt a cardiovascularis és a renalis funkció romlásával. Az összefüggés exponenciális, de mértékét az életkor jelentősen befolyásolja. A kezelés során az elérendő vérnyomás célértéke a jelenlegi adatok alapján 120-130 Hgmm között helyezkedik el a 18-65 év közötti populációban; idősebb korban - különösen 80 év felett - ennél magasabb, a $130 \mathrm{Hgmm}$ alatti érték elérése nem reális, de talán nem is szükséges. A leghelyesebb az egyéni vérnyomásprofil meghatározása, és számos befolyásoló tényezőt is figyelembe kell venni a páciens legmegfelelőbb kezeléséhez. A populáció egészségének javításához és megőrzéséhez az egyik legfontosabb és leggyakoribb cardiovascularis kockázati tényezőt, a magas vérnyomást időben fel kell fedezni, amihez a vérnyomást rendszeresen szükséges ellenőrizni, és ezzel párhuzamosan kell végezni a prevenciót célzó tevékenységeket (nevelés, oktatás, szűrés, egészségtudatos életmód) is.
\end{abstract}

Orv Hetil. 2021; 162(34): 1351-1361.

Kulcsszavak: vérnyomás, magas vérnyomás, cardiovascularis betegségek, vesebetegségek, célérték, egészségvédelem

\section{Where is the border between normal and abnormal blood pressure and what is the therapeutic goal in cardiovascular and renal diseases?}

The data in the literature suggest that the increase in the value of systolic blood pressure from $110-115 \mathrm{mmHg}$ leads to the development of atherosclerotic process and to the deterioration of cardiovascular and renal function. The correlation is initially linear, then above $140-150 \mathrm{mmHg}$ it is already exponential, but it is also related to the progression of the age. The systolic target for therapy is between $120-130 \mathrm{mmHg}$ in the population aged $18-65$; in older ages - especially over 80 years - it is higher and reaching the value below $130 \mathrm{mmHg}$ is unrealistic, and may even be not necessary. It is the best to determine the individual treatment, taking into account the individual blood pressure profile and the factors influencing the patient. In order to improve and maintain the health of the population - in addition to unknown hypertension - it is necessary to regularly monitor blood pressure and apply the known preventive methods (education, training, screening, etc).

Keywords: blood pressure, hypertension, cardiovascular disease, kidney disease, target value, health protection

Kékes E, Nagy J, Vályi P. [Where is the border between normal and abnormal blood pressure and what is the therapeutic goal in cardiovascular and renal diseases?]. Orv Hetil. 2021; 162(34): 1351-1361.

(Beérkezett: 2021. január 8.; elfogadva: 2021. február 4.) 


\section{Rövidítések}

$\mathrm{AAFP}=($ American Academy of Family Physicians $)$ Amerikai Családorvosok Akadémiája; ACC $=($ American College of Cardiology) Amerikai Kardiológiai Társaság; ACP = (American College of Physicians) Amerikai Orvosok Társasága; AHA = (American Heart Association) Amerikai Szív Társaság; ASCVB = atherosclerosisos cardiovascularis betegség; BMI = (body mass index) testtömegindex; $\mathrm{CAC}=($ coronary artery calcium $)$ coronariaartéria-kalcium; CALIBER = CArdiovascular research using LInked Bespoke studies and Electronic health Records; CI = (confidence interval $)$ konfidenciaintervallum; $\mathrm{ESC}=($ European Society of Cardiology $)$ Európai Kardiológusok Társasága; ESH = (European Society of Hypertension) Európai Hypertonia Társaság; EVA = (early vascular aging) korai érelmeszesedés; HR = (hazard ratio) kockázati arány; HYVET $=$ Hypertension in the Very Elderly Trial; ISH $=($ International Society of Hypertension) Nemzetközi Hypertonia Társaság; MESA = (Multi-Ethnic Study of Atherosclerosis) az atherosclerosis több etnikumra kiterjedő vizsgálata; MIND = Memory and Cognition in Decreased Hypertension; MRFIT = Multiple Risk Factor Intervention Trial; NICE $=$ (National Institute for Health and Care Excellence) Az Egészség és Klinikai Kiválóság Nemzeti Intézete (Egyesült Királyság); SCORE = systemic coronary risk estimation; SPRINT = Systolic Blood Pressure Intervention Trial

A magas vérnyomás definíciója többször változott az elmúlt évek során, és a különböző irányelvekben sem azonos. A nemzetközi konszenzus alapján a 2020-ban a Nemzetközi Hypertonia Társaság (International Society of Hypertension, ISH) által kiadott Hypertension Practice Guideline szerint a hypertonia definíciója a vérnyomás $\geq 140 / 90$ Hgmm-es értéke [1]. Ezt az értéket az európai országok zöme elfogadja. A Magyar Hypertonia Társaságnak a hypertonia ellátásával kapcsolatos legutóbbi, 2018-ban kiadott irányelve kimondja, hogy „Hypertonia-betegségről beszélhetünk, ha a vérnyomás rendelői körülmények között, nyugalomban, három különböző alkalommal (legalább egyhetes idóközzel), alkalmanként legalább háromszor mért értékéből az utolsó kettőnek az átlaga eléri vagy meghaladja a $140 \mathrm{Hgmm}$ systolés és/vagy $90 \mathrm{Hgmm}$ diastolés értéket". Az irányelv hangsúlyozza, hogy a hypertonia kialakulását a mérés körülményei mellett számos egyéb tényező is befolyásolja: „kor, nem, elhízás, diabetes mellitus, genetika, földrajzi régió, pszichoszociális, társadalmi és gazdasági jellemzők, stressz, alkoholfogyasztás", melyeket a dohányzással szeretnénk még kiegészíteni [2].

2020-ban Whelton SP és mtsai fontos kérdést vetettek fel: felnőtt egyéneknél a normális systolés vérnyomástartományon (90-129 Hgmm) belül melyik az a határérték, amely már összefüggést mutat a szubklinikai célszervkárosodással (az aorta és az arteria carotis distensibilitasának csökkenése) és a tünetmentes atherosclerosissal (coronariaartéria-kalcifikációval), valamint az atherosclerosisos cardiovascularis betegségekkel (ASCVB-k), ha még nincs igazolt ASCVB, és az utóbbira fokozott kockázatot jelentő tényezők sem mutathatók ki [3]?
A tanulmány eredményeit később részletesebben is ismertetjük. A kérdés megválaszolásakor azt is figyelembe kell venni, hogy az alattomosan kialakuló atherosclerosis hogyan befolyásolja egy populációban a vérnyomáseloszlást (a systolés és a diastolés vérnyomás eloszlási görbéit), valamint hogy milyen vérnyomásértékekre van szükség az egyes szervekben a megfelelő szöveti perfúzió fenntartásához [4]. Ez utóbbi pedig elvisz bennünket a J-jelenség kérdéséhez, melyról már 1-2 évtizede vitatkozunk $[5,6]$. A fenti gondolatmenetből következik, hogy érdemes újraértékelni a vérnyomás „normális” értékhatárát, hiszen ez szabja meg, hogy milyen vérnyomást tartsunk már magasnak egy vizsgált populációban, illetve hogy a hypertoniában szenvedő beteg esetében mikor indítsuk el a nem gyógyszeres és a gyógyszeres kezelést, mi legyen az a célvérnyomás, amely mellett már nem progrediálnak a magas vérnyomás okozta hemodinamikai terheléssel és a fokozott atherosclerosis-hajlammal összefüggő szervkárosodások, vagy azok még vissza is fejlődnek, az élettartam meghosszabbodik, és az életminőség is javul.

A célérték meghatározásában már jelentős közeledés van a hypertonia kezelésével foglalkozó hat legjelentősebb irányelv között (a 11 amerikai tudományos társaság közös irányelve, a továbbiakban: amerikai irányelv; a kanadai, az ausztrál, a European Society of Cardiology és a European Society of Hypertension közös irányelve, a továbbiakban: ESC/ESH irányelv; a brit National Institute for Health and Care Excellence irányelve, a továbbiakban: NICE-irányelv; az International Society of Hypertension irányelve, a továbbiakban: ISH-irányelv), hiszen a 65 év alatti egyéneknél a <130/80 Hgmm célérték kezd általánosan elfogadottá válni $[7,8]$. Ezt az előrelépést az azóta sokat kritizált SPRINT tanulmány indította el, amelynek eredményei arra utalnak, hogy a kezelés korai indítása és a <120 Hgmm systolés célérték elérése javítja a betegek életkilátásait, és szignifikánsan csökkenti a cardiovasularis halálozást és a szívelégtelenség előfordulási gyakoriságát [9].

Közleményünk célja annak tisztázása, hogy az eddigi adatok alapján valójában milyen összefüggés áll fenn a vérnyomás - elsősorban a systolés értékek - és a cardiovascularis, valamint a renalis klinikai események között. Elemezni kívánjuk Fuchs és Whelton PK koncepcióját, mely a vérnyomás, a cardiovascularis betegségek és az életkor összefüggésével foglalkozik [10].

\section{Az összefüggést vizsgáló korábbi megfigyelések}

A vérnyomásértékek és a cardiovascularis betegségek megjelenése közötti összefüggést már régóta vizsgálják. Ennek érdekében vissza kell nyúlnunk a jól ismert és a mai napig jelentős értékű Framingham és MRFIT (Multiple Risk Factor Intervention Trial) vizsgálatok adataihoz. A két tanulmányra alapozott, a systolés vérnyomásra vonatkozó összefüggést Kannel, Vasan és Levy 
1. táblázat |A vérnyomás-kategóriák és a 10 éves halmozott, életkorra illesztett, első cardiovascularis esemény incidenciája közötti összefüggés; Kannel és mtsai adatai alapján [4]

\begin{tabular}{|c|c|c|c|c|c|c|}
\hline Paraméterek & & Férfi & & & Nő & \\
\hline Vérnyomás (Hgmm) & $\begin{array}{l}\text { Optimális } \\
(<120 / 80)\end{array}$ & $\begin{array}{c}\text { Normális } \\
(120-129 / 80-84)\end{array}$ & $\begin{array}{c}\text { Magas normális } \\
(130-139 / 85-89)\end{array}$ & Optimális & Normális & Magas-normális \\
\hline $\mathrm{n}$ & 1875 & 1126 & 891 & 1005 & 1059 & 903 \\
\hline Systolés átlag \pm SD & $108 \pm 7$ & $122 \pm 5$ & $132 \pm 5$ & $111 \pm 6$ & $122 \pm 5$ & $131 \pm 6$ \\
\hline Diastolés átlag \pm SD & $70 \pm 6$ & $77 \pm 6$ & $81 \pm 6$ & $71 \pm 5$ & $78 \pm 5$ & $83 \pm 6$ \\
\hline $\begin{array}{l}10 \text { éves cardiovascularis } \\
\text { esemény }(\%)\end{array}$ & 5,8 & 7,6 & 10,1 & 1,9 & 2,8 & 4,4 \\
\hline Kockázati arány & 1 & $\begin{array}{c}1,3 \\
(1,03-1,9)\end{array}$ & $\begin{array}{c}1,6 \\
(1,1-12,2)\end{array}$ & 1 & $\begin{array}{c}1,5 \\
(0,9-2,5)\end{array}$ & $\begin{array}{c}2,5 \\
(1,6-4,1)\end{array}$ \\
\hline HR-trend, p-érték & & & $<0,01$ & & & $<0,001$ \\
\hline
\end{tabular}

$\mathrm{HR}=$ kockázati arány; SD = standard deviáció

2003-ban foglalták össze az akkor ismert adatok alapján [4]. Mindkét tanulmány elemzése arra utalt, hogy a cardiovascularis események megjelenése már 120 Hgmm systolés vérnyomásérték alatt elkezdődik, és ez a nagyobb értékek mellett, illetve az életkor előrehaladása során csak fokozódik. Az összefüggés mindkét nemben érvényesül, és nem csak a hypertonia-betegség esetében igaz. Nem meglepő, hogy a nevezett szerzők már 2003ban azt a kérdést vetették fel, amelyet Whelton PK 2020ban, nevezetesen: a systolés vérnyomás és a cardiovascularis kockázat közötti összefüggés folyamatos vagy lépcsőzetes, és megállapítható-e kritikus érték?

A felvetés jogosságát erősíti Vasan és mstai 2001-ben megjelent klasszikus tanulmánya, amelyre a fenti szerzők is hivatkoznak [11]. A Framingham-tanulmányra alapozott 10 éves összefüggés lényeges elemeit az 1. táblázatban állítottuk össze [4]. Ezen összefüggés alapján már a 140/90 Hgmm alatti kategóriákon belül is változik a cardiovascularis kockázati arány.

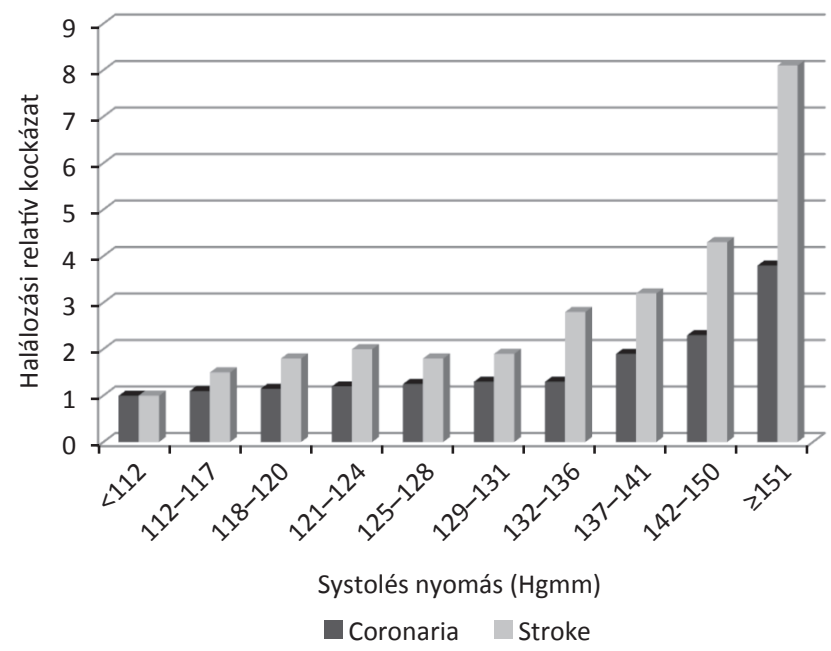

1. ábra

A systolés vérnyomás és a coronariabetegség, illetve a stroke okozta halálozás összefüggése az életkort figyelembe vevő illesztéssel. He és Whelton PK adatai [12] alapján
A másik He és Whelton PK megfigyeléses, prospektív epidemiológiai és véletlenszerü betegbesorolásos, kontrollált vizsgálatokra épülő metaanalízise, melyben szoros összefüggést állapítottak meg a systolés vérnyomás, valamint a cardiovascularis, illetve a vesebetegségek között [12]. Az összefüggés már 112 Hgmm nyomástól érvényesül. A systolés vérnyomás és a coronariabetegség, valamint a stroke okozta halálozás kapcsolatát - adataik felhasználásával - szemlélteti az 1 . ábra, amely jól mutatja, hogy az összefüggés kétlépcsős: $131 \mathrm{Hgmm}$-ig lineáris, utána gyorsan emelkedő, inkább exponenciális jellegú. Port és mtsai hívták fel először a figyelmet arra, hogy a lineáris regressziós modell nem megfelelő módszer a vérnyomás és a cardiovascularis események, illetve a mortalitás kapcsolatának jellemzésére [13]. A szerzők egy új, korspecifikus logisztikus regressziós modellt alakítottak ki, amely szerint minden adott életkorban más az összefüggés az alacsonyabb és a magasabb vérnyomású csoportokban. Ennek megfelelően a további összefüggés-elemzéseik már korcsoportok szerinti bontásban készültek. A korspecifikus összefüggést egy, a világon mindenütt idézett tanulmány bemutatásával értjük meg. Lewington és mtsai egymillió, a belépéskor tünetmentes felnőtt egyén adatait gyüjtötte össze 61, prospektív megfigyeléses tanulmányból, és elemezték a systolés vérnyomás és a vascularis (coronariabetegség, stroke, perifériás érszúkü̈let) mortalitás kapcsolatát 40-89 év között, bontott korcsoportok szerint [14]. Az eredeti közleményben a vascularis mortalitás kockázatát logaritmikus transzformációval adták meg. A kockázat 115 Hgmm systolés vérnyomásértéktől folyamatosan és lineárisan emelkedett, $20 \mathrm{Hgmm}$-es emelkedés megkétszerezte a cardiovascularis halálozást. Minél idősebb az egyén, annál nagyobb a kockázat. Fuchs - logaritmikus transzformálás nélkül - ugyancsak nagyszámú prospektív vizsgálat alapján elemezte az összefüggést ugyanazon életkori és systolés vérnyomásos tartományokban [10, 15]. Mindkét módszerrel a systolés vérnyomás növekedésével párhuzamosan exponenciális összefüggés látható minden korcsoportban. Fuchs elemzésében relatíve kisebb növe- 

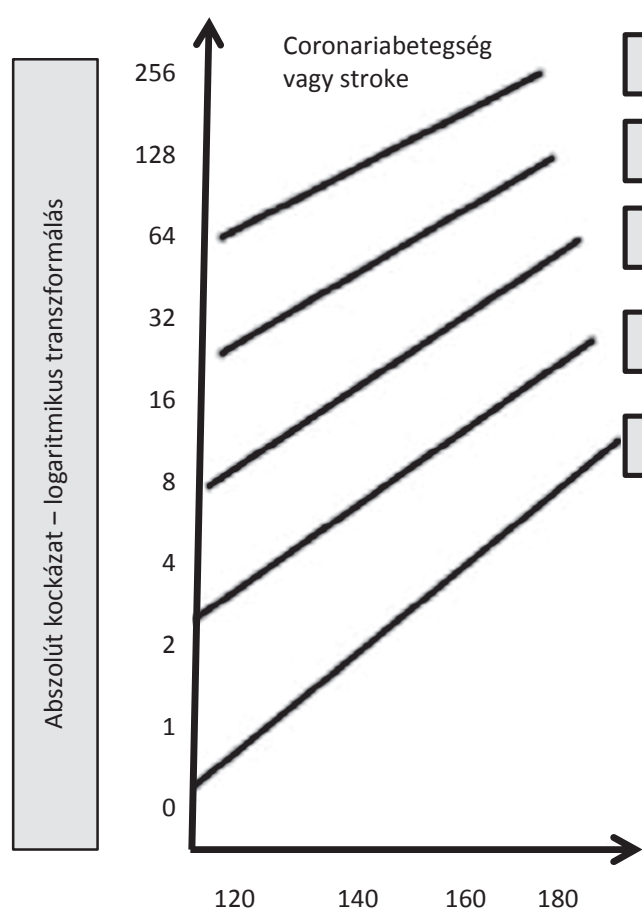

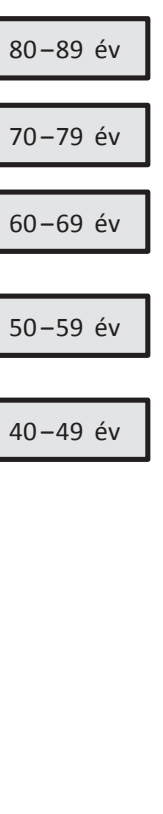

Systolés vérnyomás
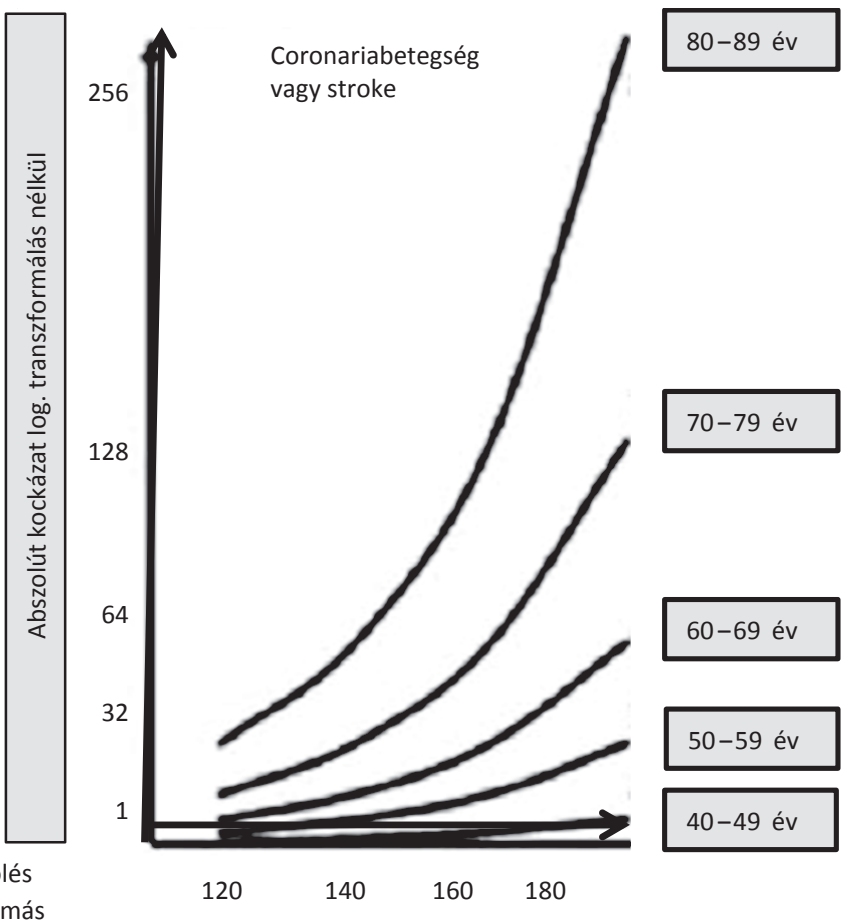

2. ábra

A cardiovascularis betegség (coronariabetegség vagy stroke) okozta halálozás abszolút kockázata a vérnyomásértékek, valamint a korcsoportok függvényében. A systolés vérnyomás és a cardiovascularis betegség (coronaria vagy stroke) összefüggése - abszolút kockázat - lineáris (logaritmikus transzformált) (baloldalt) és exponenciális (nem logaritmikus transzformáció) értékeléssel (jobboldalt). Lewington [14] és Fuchs [15] adatai alapján

kedés volt a systolés vérnyomás emelkedése folyamán és a fiatalabb korcsoportokban. A két elemzést mutatjuk be a 2. ábrán $[14,15]$.

Ezen megfigyelések alapján a systolés vérnyomásértékek és a cardiovascularis betegségek kapcsolatáról a következőket lehet mondani:

- minél idősebb a személy, annál nagyobb az adott vérnyomásértékekhez tartozó cardiovascularis kockázat;

- amennyiben a két ábrázolási módszert figyelembe vesszük, akkor bizonyos különbség van a két összefüggés között. A Lewington-féle értékelés (2. ábra, baloldalt) arra utal, hogy fiatalabb korban kis vérnyomásemelkedés is jelentősen növelheti a kockázatot - itt valószínú, hogy nagyobb arányban az idősebb populáció dominált; a Fuchs-féle (2. ábra, jobboldalt) értékelés szerint fiataloknál az összefüggés csaknem lineáris, itt inkább fiatal és középkorú egyének domináltak;

- mindkét összefüggésben az idős korosztályoknál a gyors emelkedés fő okozója a társbetegségek megjelenése.

A fentiekból következik az adott nemhez és korhoz tartozó normális határ-, illetve küszöbértékek új értelmezése is. Ezzel lehet magyarázni, hogy idős egyéneknél (HYVET vizsgálat) a 150 Hgmm systolés vérnyomásérték alá történő csökkentés milyen kedvezően befolyásolta a cardiovascularis halálozást $(-23,7 \%)$, illetve a szívelégtelenség kialakulását $(-64 \%)$ [16]. Ugyanakkor az is logikusan következik, hogy 140 Hgmm systolés vérnyomás felett minél idősebb az egyén, annál kisebb vérnyomás-emelkedés is gyorsan és nagymértékben növeli a cardiovascularis kockázatot.
A régi, klasszikus tanulmányok - nagy létszámú prospektív vizsgálatok alapján - egyértelmúen szignifikáns összefüggést írtak le a vérnyomás-emelkedés és a vesefunkció romlása között, amelynek oka az afferens arteriolák hyalinisatiója és sclerosisa, és ez a vérnyomás-emelkedés mértékének megfelelően a glomerularis funkció romlásához vezet. A tünetek hosszú évekig nem jelentkeznek, majd a legtöbbször a microalbuminuria az első tünet. Az összefüggés a systolés és a diastolés vérnyomás vonatkozásában egyaránt érvényes [17, 18].

\section{A vérnyomás, a cardiovascularis és a renalis események összefüggését vizsgáló újabb tanulmányok}

Az egyik jelentős elemzés Rapsomaniki munkacsoportjától származik, akik Angliában 225 háziorvosi praxis pácienseinek elektronikus betegdokumentációját dolgozták fel a CALIBER (CArdiovascular research using LInked Bespoke studies and Electronic health Records) programmal [19]. A feldolgozásban a praxisok adatainak, a Nemzeti Myocardialis Infarctus Regiszternek, a kórházi eseményeknek és a halálozási adatbázisnak a vezetése egyeztetett formában történt. A program megfelelő múködését egy másik munkacsoport ellenőrizte. Az elektronikus betegkartonok adatai alapján 1,25 millió, 30 év feletti egyén vérnyomásadatait gyưjtötték össze 1997 és 2010 között, akiknek a rendszerbe kerülésekor még nem volt bizonyított a cardiovascularis betegségük. Az egyének között 416900 hypertoniás beteg volt. Három kor- 
Az ismételt mérések alapján (5 év) számolt systolés vérnyomásértékek és a cardiovascularis betegségek, illetve a krónikus vesebetegségek közötti öszszefüggés többváltozós Cox-regresszióval, illesztett kockázati aránnyal (hazard ratio - HR). Az illesztés kor, nem, testtömegindex, LDL-koleszterin, becsült glomerulusfiltrációs ráta, antihypertensiv és lipidcsökkentő gyógyszeres kezelés alapján történt. Wan és mtsai [21] adatai alapján

\begin{tabular}{|c|c|c|c|c|c|c|c|}
\hline Systolés vérnyomás (Hgmm) & $<115$ & $115-124$ & $125-134$ & $135-144$ & $145-154$ & $155-164$ & $\geq 165$ \\
\hline Létszám & 21126 & 43144 & 65369 & 63216 & 40176 & 20591 & 13847 \\
\hline $\begin{array}{l}\text { Cardiovascularis betegség } \\
\text { előfordulási aránya ( } 1000 / \text { év })\end{array}$ & 17,1 & 18,6 & 19,9 & 21,9 & 23,1 & 22,6 & 21,9 \\
\hline Kockázati arány $(95 \%$ CI) & $\begin{array}{c}1,00 \\
(0,82-1,22)\end{array}$ & $\begin{array}{c}1,09 \\
(1,03-1,17)\end{array}$ & $\begin{array}{c}1,14 \\
(1,1-1,19)\end{array}$ & $\begin{array}{c}1,27 \\
(1,23-1,31)\end{array}$ & $\begin{array}{c}1,35 \\
(1,28-1,41)\end{array}$ & $\begin{array}{c}1,49 \\
(1,36-1,63)\end{array}$ & $\begin{array}{c}1,89 \\
(1,66-2,15)\end{array}$ \\
\hline $\begin{array}{l}\text { Krónikus vesebetegség } \\
\text { előfordulási aránya ( } 1000 / \text { év) }\end{array}$ & 16,2 & 17,3 & 19,6 & 23,4 & 26,2 & 25,8 & 24,2 \\
\hline Kockázati arány (95\% CI) & $\begin{array}{c}1 \\
(0,82-1,22)\end{array}$ & $\begin{array}{c}1,01 \\
(0,94-1,07)\end{array}$ & $\begin{array}{c}1,15 \\
(1,1-1,19)\end{array}$ & $\begin{array}{c}1,41 \\
(1,37-1,46)\end{array}$ & $\begin{array}{c}1,63 \\
(1,56-1,7)\end{array}$ & $\begin{array}{c}1,95 \\
(1,79-2,12)\end{array}$ & $\begin{array}{c}2,9 \\
(2,55-3,28)\end{array}$ \\
\hline
\end{tabular}

$\mathrm{CI}=$ konfidenciaintervallum; LDL $=$ kis denzitású lipoprotein

csoportban (30-59 év, 60-79 év és $\geq 80$ év) külön-külön vizsgálták a systolés és a diastolés vérnyomás egyes értékei és a cardiovascularis betegségek egyes formái (angina, myocardialis infarctus, stroke, aortaaneurizma, érszúkület stb.) közötti összefüggéseket. Az elemzés azért is értékes, mert a systolés értéktartományok 90-114, 115$129,130-139,140-159,160-179$ és $\geq 180 \mathrm{Hgmm}$, a diastolés értéktartományok 60-74, 75-84, 85-89, 9094, 95-99 és $\geq 100$ Hgmm voltak. Az adatok igen alkalmasak voltak arra, hogy a normális-kóros vérnyomáshatárérték vonatkozásában értékelhetók legyenek. A betegségformák és a vérnyomásérték kapcsolatát kockázati aránnyal (hazard ratio) fejezték ki. Elemzésük bizonyította, hogy

- a systolés és a diastolés vérnyomás tekintetében a cardiovascularis események növekedése egyaránt folyamatos, azaz már igen alacsony systolés, illetve diastolés vérnyomásértékeknél is számolni kell a cardiovascularis kockázat növekedésével;

- a J-fenomén jelenlétét a tanulmány nem igazolta;

- a systolés vérnyomás prognosztikai jelentősége nagyobb a diastoléssal összehasonlítva, kivéve az aortaaneurizmát, amelynél igen jelentős kockázat a diastolés vérnyomás emelkedése;

- a magasabb vérnyomásértékeknél már nem lineáris, hanem exponenciális az összefüggés, különösen a 3059 éves korcsoportban.

Annyiban igaza van Whelton PK-nak [10], hogy a kor elörehaladtával természetesen egyre nagyobb a cardiovascularis betegségek jelenlétének kockázata, másrészt ezen elemzés Lewington [14] igazát is jelzi, miszerint a közepes felnőtt korban (30-59 év között) már kis vérnyomás-emelkedés is nagymértékben, akár végzetesen emeli a cardiovascularis betegségek megjelenésének kockázatát. Kiemelt jelentősége van, hogy a számos közleményben leírt J-fenomént [20] nem tudták igazolni.

A 2019-ben publikált Honkong-tanulmány további újabb megfigyeléseket nyújt számunkra. Wan és mtsai [21] 267469 olyan hypertoniás egyén vérnyomását követték 5 éven keresztül, akiknél az indításkor nem volt cardiovascularis betegség, diabetes vagy krónikus vesebetegség. Kétfajta vérnyomás-értékelés történt: az egyikben az alapértékeket, a másikban a vérnyomás ismételt méréseinek átlagát (az 5 éves mérések átlaga) vették alapul az összefüggés vizsgálatakor. Többváltozós Cox-féle regressziós modellt alkalmazva illesztett kockázati aránynyal (hazard ratio [HR], a 95\%-os konfidenciaintervallumot $[\mathrm{CI}]$ is megadva) elemezték a systolés vérnyomás és a cardiovascularis betegség (coronariabetegség, stroke, szívelégtelenség), valamint a krónikus vesebetegség megjelenésének összefüggését (2. táblázat) [21]. Az összefüggés - az előző vizsgálatokhoz hasonlóan - exponenciális típusú, azaz a kockázati arány már 115 Hgmm felett azonnal emelkedik. A közlemény szupplementumában további értékes adatokat mutatnak be (3. ábra) $[21,22]$ :

- a vérnyomás és az események megjelenése között a kezelt hypertoniás egyéneknél is nemlineáris összefüggés áll fenn;

- a J-fenomén akkor észlelhető, ha az alap-vérnyomásértékekhez viszonyítjuk az eseményeket, az ismételt méréseknél ez csaknem eltûnik, speciális statisztikai elemzés során már nem mutatható ki (3 ábra, jobb oldal);

- ez az értelmezés azt is jelenti, hogy $110 \mathrm{Hgmm}$ systolés értéktól kezdve gyakorlatilag nincs küszöbérték, hanem az események gyakorisága folyamatosan emelkedik;

- a vesebetegség megjelenése szignifikánsan gyorsabban emelkedik a systolés vérnyomás növekedésével.

Fuchs és Whelton PK 2020-ban összegezték [10] az eddigi régebbi és újabb elemzések eredményeit. Hangsúlyozták, hogy a régebbi vizsgálatok csak a hypertonia „korai” komplikációira koncentráltak, elsősorban a coronariabetegségre és a stroke-ra, azonban a késői - és a kor előrehaladtával összefüggő - szövődményekkel (szívelégtelenség, hypertensiv cardiomyopathia, pitvarfibrilláció, dementia stb.) nem foglalkoztak. A régi, helyes következtetések továbbvitelét jelentette a SPRINT tanulmány, melyben a célérték < $20 \mathrm{Hgmm}$ systolés vérnyomás alá vitele $43 \%$-kal csökkentette a cardiovascularis 

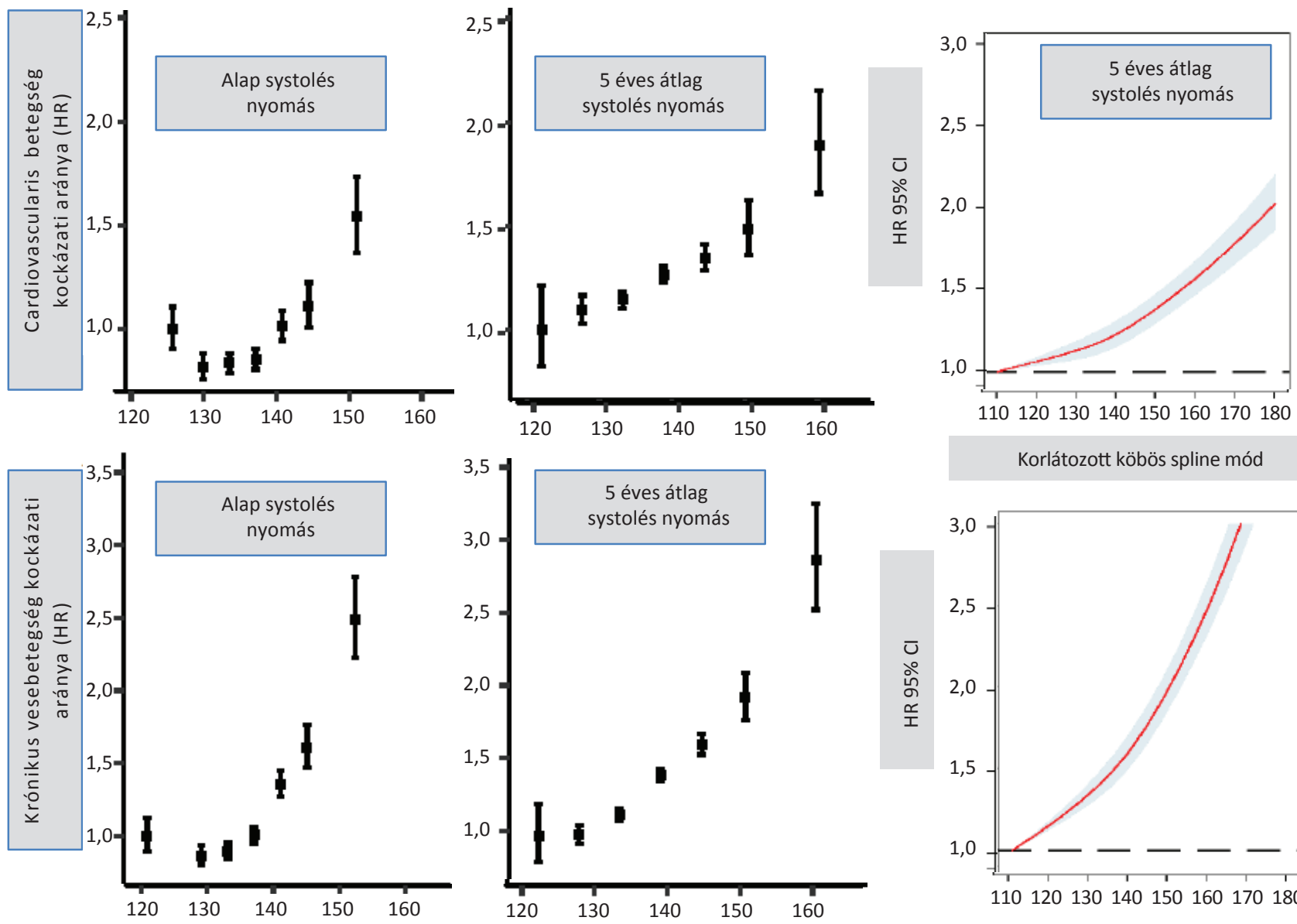

Korlátozott köbös spline mód

3. ábra

\begin{abstract}
A vérnyomás (alap és 5 éves átlag systolés nyomás) és a cardiovascularis, illetve vesebetegség incidenciája közötti összefüggés vizsgálata többváltozós Cox-regressziós modellben elemzett proporcionális hazárd aránnyal (baloldalt és középen), illetve proporcionális hazárd aránnyal, de korlátozott köbös 'spline' ábrázolással [22] (jobboldalt) bemutatva. Az utóbbi statisztikai értelemben a legmegfelelőbb az ilyen többdimenziós változók összefüggés-vizsgálatához. A kockázati arány meghatározása a kor, a nem, a dohányzás, a BMI, a diastolés vérnyomás, az LDL-koleszterin, a becsült glomurulusfiltrációs ráta, az antihypertensiv és a lipidcsökkentő szerek figyelembevételével történt. A Honkong-tanulmány [21] adatai alapján
\end{abstract}

$\mathrm{BMI}=$ testtömegindex $\mathrm{CI}=$ konfidenciaintervallum; $\mathrm{HR}=$ kockázati arány $\mathrm{LDL}=$ kis denzitású lipoprotein

és 27\%-kal az összmortalitást [9, 23]. A 120 Hgmm alatti cél végül nem teljesült, de az addigi legalacsonyabb célértékeket érték el. Másrészt hangsúlyoznunk kell, hogy nem a szokványos, hanem speciális vérnyomásmérési technikát alkalmaztak, mellyel a klinikai gyakorlatban szokásos mérésnél alacsonyabb vérnyomásértékeket kaptak. Kiemelést érdemel, hogy az intenzív vérnyomáscsökkentő kezelés még a 75 év feletti populációban is szignifikánsan mérsékelte a cardiovascularis halálozás előfordulási arányát, kis mellékhatás-gyakorisággal (például hypotonia) [24]. A SPRINT tanulmányt sorban követték a nagy értékú, megbízható klinikai vizsgálatok, amelyek tovább erósítették azt a koncepciót, hogy a lehetô legkedvezőbb alacsony értékben kell a célértéket megadni, mert ennek prevenciós hatása igen eredményes. Ettehad és mtsai [25] 613815 hypertoniás egyénre (123 vizsgálat) kiterjedő metaanalízise igazolta, hogy a $130 \mathrm{Hgmm}$ alatti systolés célérték alkalmazása szignifikánsan csökkentette a cardiovascularis események, a coronariabetegség, a stroke, a szívelégtelenség, a veseelégtelenség megjelenésének arányát és az összmortalitást. Bundy és mtsai [26] 2017-ben 42, véletlenszerü beteg- besorolásos klinikai tanulmányt tartalmazó metaanalízisükben (144 220 beteg) igazolták, hogy a 120-124 Hgmm systolés vérnyomás a legkedvezőbb célérték, amikor a magasabb célértékekkel hasonlították össze a kimenetelt. A 140-144 Hgmm systolés célértékkel történő összehasonlításkor (a kockázati arány alapján) a stroke elöfordulása 45\%-kal, a coronariabetegségé 31\%kal és a cardiovascularis halálozásé 45\%-kal csökken. A SPRINT-MIND vizsgálatban a <120 Hgmm systolés célérték mérsékelten kedvező eredményeket adott, az agyi fehérállomány érintettsége szignifikánsan kisebb lett, és csökkent a kognitív károsodás [27, 28]; direkt független összefüggést azonban nem igazoltak [29].

Ezek után logikus Whelton SP és mtsai 2020-ban publikált [3] új elemzését is bemutatni. Elgondolásuk az, hogy a „civilizált”, iparosodott társadalmakban a korral együtt automatikusan növekszik a vérnyomás a fennálló és állandósuló kockázati tényezők (nagy sóbevitel, alacsony gyümölcs/zöldség fogyasztás, elhízás, csökkent fizikai aktivitás) miatt. A vérnyomás emelkedésével együtt folyamatosan növekszik az atheroscleroticus cardiovascularis betegség elöfordulása. Kérdés, hogy ez a 
folyamat mikor indul el, lehet-e határértéket mondani, amely érték felett már kezd növekedni a kockázat, hiszen ehhez kell igazodni a hypertonia kezelésekor a célértékeknek is. Ma már a 18-65 év közötti személyek számára nem <140 Hgmm a systolés célérték, hanem <130 Hgmm [1, 2]. Az eddigi elemzéseknél a vérnyomás és az események közti összefüggést 115 vagy 120 Hgmm-től mint referenciaértéktől indítják, bár Rapsomaniki és mtsai [19] a tanulmányukban már 90-114 Hgmm-től indultak, de metaanalízis eredménye alapján. Whelton $S P$ a kérdést másképp közelítette meg. Az elemzés alapját a MESA (Multi-Ethnic Study of Atherosclerosis) vizsgálat [30] adta, melyben a bevonáskor (2000 és 2002 között) a résztvevőknél nem volt kimutatható atheroscleroticus cardiovascularis betegség. Ebből a kohorszból külön elemzett 1457, 30 év feletti egyént (átlagéletkor: 58,1 év), akiknél az alap systolés vérnyomás 90-129 Hgmm között volt. A kiválasztott egyéneknél nem volt dyslipidaemia, diabetes, nem dohányoztak, és nem kaptak antihypertensiv vagy lipidcsökkentő kezelést. Az értékeléskor a cardiovascularis események megjelenését 2018 és 2020 között (14,5 éves átlagos megfigyelés idő), a 10 éves ASCVB-kockázatot, valamint a coronariaartériakalcium (CAC) jelenlétét vették figyelembe. A CACelemzésnél komputertomográfiával mért két értéket adtak meg: az egynél több coronariaágon kimutatható kalcium \%-ban, vagy diffúz kalcifikáció áll fenn [31]. Az elemzés legfontosabb adatait a 3. táblázatban mutatjuk be. Az eredmények interpretálása azt rögzíti, hogy 90 Hgmm-es systolés vérnyomástól kezdődően - az emelkedő vérnyomásértékek során - fokozatosan nő az atherosclerosis-eredetú cardiovascularis események megjelenésének kockázata és ezzel együtt a coronariaartéria kalciumtartalma. A kockázatot a kockázati aránnyal és az illesztett hazárdértékkel igazolták. A pozitív összefüggés akkor is fennállt, ha folyamatos változóként köbös 'spline' elemzést alkalmaztak. A végső konklúzióban Whelton SP kimondja, hogy a normális systolés vérnyomástartományon belül (90 Hgmm-tól) a vérnyomás minden $10 \mathrm{Hgmm}$-es emelkedése az atherosclerosis-ere- detû cardiovascularis események kockázatát 53\%-kal növeli (illesztett kockázati arány $[95 \%$ CI] 1,53 [1,171,99]) [3].

\section{Mit nyújtanak számunkra ezen elemzések?}

A systolés vérnyomás és a kardiometabolikus-renalis események között sajátos szignifikáns összefüggés áll fenn, amely összefügg a civilizáció, az iparosodás kialakulásával és ezek fejlődésével. A összefüggés nem lineáris, mint régebben hitték, hanem kétfázisú: az alacsony értékeknél lineáris és a 140-150 Hgmm közötti értéktől exponenciális típusú. A diastolés vérnyomás és az atherosclerosis okozta cardiovascularis események között is van összefüggés, ez azonban nehezebben értékelhető, elsősorban a diastolés vérnyomás időskorban kialakuló jelentős esése miatt. A vérnyomás és az életkor közötti összefüggés alapja, hogy a civilizált populációkban az atherosclerosis alattomosan és folyamatosan alakul ki, jóval a klinikai tünetek megjelenése előtt. Azok a celluláris és funkcionális változások (oxidatív stressz, mitochondrialis diszfunkció, krónikus alacsony fokú inflammatio, genomikai instabilitás, alacsony intenzitású protein-homeostasis stb.), amelyek szervezetünk érrendszerében - a micro- és a macrovascularis struktúrában egyaránt - végbemennek, hozzák létre a szöveti károsodásokat, majd a betegségeket [32]. Hypertoniában, illetve általában a systolés vérnyomás tekintetében a korral együtt járó növekedés rendszerint párhuzamos az atherosclerosis okozta folyamattal, illetve az ezt mérő artériás merevség (stiffness) folyamatos növekedésével [33]. Mindez megbízhatóan mérhető a CAC-pontrendszer alapján is [34]. Az életkor és az atherosclerosis kapcsolata önmagában is bonyolult, hiszen jól ismert, hogy a populáció egy jelentős részében a korai érelmeszesedés, „early vascular aging” (EVA) jelensége alakul ki a normális „healthy vascular aging” jelenségével szemben, sőt már új elnevezést is adtak azon jelenségre (SUPERNOVA = szupernormális vascularis öregedés), amelynek során a kor előrehaladtával igen alacsony marad az artériás merevség [35].

3. táblázat | A $130 \mathrm{Hgmm}$ alatti systolés vérnyomáscsoportokban a systolés nyomás és a 14,5 éves megfigyelési idő alatt megjelenő cardiovascularis események, a 10 éves cardiovascularis kockázat, valamint az ezeknek megfeleló illesztett (diastolés vérnyomást, összkoleszterint, HDL-koleszterint, éhomi vércuk rot, BMI-t, jövedelmet, képzettségi szintet, dohányzást, praediabetest figyelembe vevő) kockázati arány (HR) (Cox-regresszió) összefüggése. A táb lázat mutatja a coronariakalcifikáció-elemzést is $(\mathrm{CAC} \geq 1) \%$-ban. Whelton SP és mtsai adatai [3] alapján

\begin{tabular}{|c|c|c|c|c|c|}
\hline Systolés nyomáscsoportok (Hgmm) & $90-99$ & $100-109$ & $110-119$ & $120-129$ & Trend, $\mathrm{p}$ \\
\hline Systolés nyomásátlagok (Hgmm) & 98 & 106,3 & 115,7 & 122,8 & $<0,01$ \\
\hline Diastolés nyomásátlagok (Hgmm) & 60,1 & 65,6 & 69,6 & 71,4 & $<0,01$ \\
\hline BMI $\left(\mathrm{kg} / \mathrm{m}^{2}\right)$ & 24,4 & 26,7 & 27 & 27,9 & $<0,01$ \\
\hline $\mathrm{CAC} \geq 1(\%)$ & 19,7 & 25,6 & 28,4 & 40,8 & $<0,01$ \\
\hline Cardiovascularis esemény (1000/év) & 0,4 & 3,7 & 4,7 & 7,9 & $<0,001$ \\
\hline 10 éves cardiovascularis kockázat & 1,1 & 2,1 & 3,3 & 5,6 & $<0,001$ \\
\hline Illesztett arányos kockázati arány $(95 \% \mathrm{CI})$ & 1 & $3,00(1,01-8,8)$ & $3,1(1,03-9,28)$ & $4,58(1,47-14,27)$ & $<0,05$ \\
\hline
\end{tabular}

$\mathrm{BMI}=$ testtömegindex $; \mathrm{CAC}=$ coronariaartéria-kalcium; $\mathrm{CI}=$ konfidenciaintervallum; $\mathrm{HDL}=$ nagy denzitású lipoprotein 
A folyamat általában felgyorsul a középső felnőtt életkorban (40-50 év felett), ezzel magyarázható szerintünk a vérnyomásérték és a cardiovascularis betegség közötti nem lineáris kapcsolat, illetve az is, hogy a systolés vérnyomás növekedésével - küszöbérték nélkül - egyenletesen emelkedik a cardiovascularis események száma. Mindezeken túl természetesen genetikai tényezőkkel (fenotípusok) is kell számolni, de ennek mélyebb elemzésére nincs lehetőség ezen közleményben.

A legújabb kutatások arra irányulnak, hogy pontosan tisztázzák, melyek azok a tényezők (genetikai, életmódtípusok, környezeti, epigenetikai stb. hatások), amelyek előidézik az EVA-t vagy éppen a SUPERNOVA-típust. Az artériás merevség mint mérce jelentóségére utal, hogy a SPRINT tanulmány egyik utóelemzése szerint jobb a túlélés azon esetekben, amelyekben a becsült aortamerevség nagyobb mértékben csökkent, mint a vérnyomásérték [36].

A másik fontos következtetés, hogy az eddigieknél is nagyobb mértékben és minél korábban (már korai gyermekkorban) el kell kezdeni az atherosclerosis és ezzel együtt a magas vérnyomás prevencióját (helyes étrend, kisebb konyhasóbevitel, optimális kalóriabevitel, fizikai aktivitás, a dohányzás elleni küzdelem), mert csak így lehet az EVA kialakulását gátolni, illetve lassítani.

\section{Mikor indítsuk a kezelést, és mi legyen a helyes célérték?}

Mind a hypertonia gyógyszeres kezelésének elindítása, mind a célérték tekintetében közelebb került az északamerikai és az európai irányelv [37, 38]; bizonyos különbségek mégis fennállnak, és ez elsősorban a normális vérnyomás definíciójával és a vérnyomásmérési technikával függ össze. A mérés egységesítése és helyes értelmezése [1] közel hozza a rendelői, az otthoni és az ambuláns vérnyomás-monitorozás nappali értékeit [39]. A hypertonia definíciójának módosítása a 2017. évi AHAirányelvben (normális vérnyomás: <120/<80 Hgmm) nem csak az összes hypertoniás egyén létszámát növelte, ugyanakkor talán haszon is [40], mert az új definíció mellett jobban fel tudjuk ismerni a nem kezelt hypertoniások esetében a nagy cardiovascularis kockázattal és a normális érték feletti vérnyomással rendelkező egyéneket. A gyógyszeres kezelés elindításának küszöbértékei és a célértékek „számtani értelemben” közelebb kerültek a terápiás irányelvekben, ha a 18-65 éves felnőtt korcsoportot vizsgáljuk, azonban 60-65 év felett már jelentős eltéréseket figyelhetünk meg, amelyek esetén még messze van a „konszenzus”, sőt a 60 év feletti hypertoniás populáció kezelése terén még az Egyesült Államokon belül is (ACC/AHA, illetve ACP/AAFP irányelvek) jelentős véleménykülönbségek fogalmazódtak meg [41]. Carey és Whelton PK [42] 9, véletlenszerü betegbesorolásos klinikai tanulmány alapján összesítették a vérnyomáscsökkentés mértékét és a célértékeket különböző systolés vérnyomásértékek figyelembevételével és összehasonlításával.
Véleményük szerint ma már igen erős bizonyítékkal rendelkezünk ahhoz, hogy kimondhassuk: a <130 Hgmm systolés célérték az optimális. Bangalore és mtsai [43] szerint a $<120 \mathrm{Hgmm}$ systolés célérték is hasznosnak bizonyul. Számolnunk kell azzal is, hogy az egyes szerveinkben különböző az optimális perfúzióhoz szükséges vérnyomás. Optimális célértéknek 18-65 év között biztosan a 120-130 Hgmm systolés vérnyomás látszik. A diastolés értéket erősen befolyásolja az életkor, és inkább a pulzusnyomás nagyságának értékét hangsúlyozzák, de ezzel a közlemény terjedelme miatt nem foglalkozunk. A kérdés azonban messze nem ilyen egyszerü, melyre a legjobb választ Mancia adja [44]. Véleménye szerint a gyakorló orvos számára - különösen az idős korcsoportokban - még a 140 Hgmm alatti systolés vérnyomás elérése sem könnyü, és a < 130 Hgmm alatti célérték szinte lehetetlen. Másrészt minél szigorúbb célértéket alkalmazunk, annál nagyobb lesz a mellékhatások előfordulása. Ez a hypertoniás populáció jelentős részét érintő idős vagy nagyon idős egyéneknél súlyos következményekkel járhat.

\section{Milyen utat járhatunk a jövőben?}

A kérdést két oldalról kell megközelítenünk.

Az egyik a populációs szintü értelmezés, amely szerint a vérnyomás kontrollja (a célérték elérése), ezen belül az átlagos systolés vérnyomás csökkentése, az adott populációban - az egészségügy helyzetének, támogatásának, a mérési technikáknak, a beteg és a kezelésben részt vevők (team) felvilágosításának, nevelésének függvényében fokozatosan az alacsonyabb átlagértékek felé halad. A legjobban ezt a trendet az 'NCD Risk Factor Collaboration' 2019. évi elemzése [45] igazolja, mely szerint 12, gazdaságilag fejlett országban 2000 és 2017 között minden korcsoportban folyamatosan növekedett a megfelelően kezelt hypertoniás betegek aránya. Ezzel együtt jár a vérnyomás eloszlási görbéinek jobbról balra tolódása (az alacsonyabb átlagértékek felé) [46].

A másik megközelítés, hogy adott páciensnél milyen sikerrel tudjuk megfelelően ellenőrizni a vérnyomást, elérni a célértéket, és mennyire tudjuk az elért célértéket tartósan fenntartani. Ezt a kezelés és a gondozás hatékonyságát befolyásoló tényezők szabják meg:

- az ellátó egészségügyi munkacsoport (orvos, ápoló, asszisztens, gyógyszerész) szakmai tudása, tapasztalata;

- az ellátóteam kommunikációs készsége;

- a beteg kora, neme, pszichoszociális állapota, társadalmi-gazdasági helyzete, egészségkultúrája;

- az ellátórendszer keretein belül az optimális betegutak biztosítása;

- a betegoktatás minősége;

- az otthoni vérnyomásmérés (önmérés, vérnyomásnapló vezetése);

- modern informatikai, telemedicinális eszközök (web, SMS, okostelefon, táblagépek) és szoftverek (alkalmazások) használata. 
A komplex módszer sikeres megvalósítását több külföldi és hazai vizsgálatban igazolták [47-49].

A modern orvoslásban egyre inkább az ember egészségének, és nem a betegségének kell a középpontban állnia. Egyre jobban el kell terjednie az ún. $4 P$ (prevenció, predikció, perszonalizált ellátás, partnerség) egészségmodellnek.

Az emberek legyenek tudatában annak, hogy:

- miért fontos, és mit jelent a betegségek megelőzése vagy a már fennálló betegség súlyosbodásának prevenciója;

- előre meg kell mondani, hogy a megelőzési tevékenység milyen eredménnyel jár, a gyógyítási, rehabilitációs folyamatnak milyen kilátásai vannak;

- az ember öröklött és szerzett személyes tulajdonságai, a szúkebb és tágabb környezettel való viszonya, egyensúlya hogyan befolyásolja a személyre szabott ellátását;

- az érintett, megfelelő egészségmúveltséggel rendelkezó személytől el kell várnunk az aktív részvételt, ezzel is hangsúlyozva személyes felelősségét az egészség megörzésében, betegség esetén az ellátási folyamat minden lépéséről közérthetően tájékoztatni kell, a döntéseket pedig közösen kell meghozni, és a felelősséget is meg kell osztani.

Teljesen meg kell változnia az orvos-beteg viszonynak, az ún. követő, a történések után futó orvoslástól el kell jutnunk az előrelátó, aktívan cselekvő medicináig [5052].

A jelenleg rendelkezésre álló lehetőségek kihasználásával már az alapellátás szintjén - még inkább, ha a csoportpraxis megvalósul - az alábbi alapelveket és gyakorlati tanácsokat adhatjuk:

- Magyarországon jogszabályok határozzák meg, hogy a lakosság egészségi állapotát rendszeresen fel kell mérni. A magyar egészségügyi törvény pontosan leírja a szûrővizsgálatok végzésének feltételeit [53]. Hazánkban 1997 óta hatályban van a betegségek megelőzését és korai felismerését szolgáló szűrővizsgálatok rendjét szabályozó miniszteri rendelet, amelyet 2005ben az európai és az amerikai prevenciós irányelveknek megfelelően korszerüsítettek [54]. A rendelet melléklete tartalmazza az életkori sajátosságokhoz igazodó szűrővizsgálatokat. A rendelet szerint „az egészségügyi szolgáltatás igénybevétele során a háziorvos és a házi gyermekorvos az adott korcsoport számára ajánlott valamennyi, a szakellátás orvosa pedig a kompetenciájába tartozó szűrővizsgálatok igénybevételének a lehetőségére köteles felhívni az általa ellátott biztosított, illetve törvényes képviselője figyelmét”. A rendelet gyermekkorban meghatározza a védőnő és a gyermek/iskolaorvos által kötelezően elvégzendő vizsgálatokat. A felnőttkori alapstatust 21 éves korban javasolt meghatározni, ez magában foglalja a családi anamnézis frissítését, beleértve a korai életkorban jelentkező szívkoszorúér-betegségre, érelmeszesedéssel kapcsolatos szélütésre, verőérszúkúletre vonatkozó adatokat, az életmódi tényezők feltárását, a részletes fizikális vizsgálatot, magas vérnyomás, elhízás, diabetes mellitus esetén a fokozott kockázat felderítését célzó kiegészítő vizsgálatokat, a teljes cardiovascularis kockázat felmérését a SCORE-pontrendszer alapján. A kockázat mértékétől függően 2-5 évente meg kell ismételni az állapotfelmérést, fokozott cardiovascularis kockázat esetén a tünetmentes atherosclerosis irányában is ki kell egészíteni a vizsgálatokat (a boka-kar index meghatározása, carotis- és femoralis ultrahangvizsgálat, brachiofemoralis pulzushullám terjedési sebessége stb.);

- a magyar „szürési” rendelet összhangban van a nemzetközi irányelvekkel is: mivel $115 \mathrm{Hgmm}$ systolés vérnyomás felett már biztosan megindul az atherosclerosis folyamata a civilizált országok populációjában - bár különböző gyorsasággal -, indokolt a teljes cardiovascularis kockázatnak, a tünetmentes atherosclerosisra utaló jeleknek az időszakos vizsgálata;

- az irodalmi adatok szerint már 130 Hgmm systolés vérnyomás felett indokolt a vérnyomás kezelésének menetét meghatározni;

- a helyes célérték felnőtt egyénnél 80 éves korig biztos <130 Hgmm, de optimálisnak a 120-124 Hgmm érték látszik. Ennél a legkisebb a cardiovascularis és a vesebetegség kialakulásának kockázata. 80 év felett egyedi meghatározás szükséges, a fizikai és szellemi törékenység figyelembevételével;

- a társbetegségek és a törékenység megítélése már 65 év felett is szóba jön, egyéni megítélés alapján;

- a hypertoniás beteget folyamatosan kell kezelni és gondozni, az irányelvekben megszabott előírások alapján.

Anyagi támogatás: A közlemény megírása anyagi támogatásban nem részesült.

Szerzői munkamegosztás: K. E., N. J. és V. P. egyenlő arányban végezte az irodalmi kutatást, az elemzést és a közlemény szövegezését. A cikk végleges változatát valamennyi szerző elolvasta és jóváhagyta.

Érdekeltségek: A szerzóknek nincsenek érdekeltségeik.

\section{Irodalom}

[1] Unger T, Borghi C, Charchar F, et al. 2020 International Society of Hypertension global hypertension practice guidelines. Hypertension 2020; 75: 1334-1357.

[2] Hungarian Society of Hypertension. Guidelines for the treatment of hypertension. [A Magyar Hypertonia Társaság Szakmai Irányelve. A hypertoniabetegség ellátásának irányelvei.] Hyperton Nephrol. 2018; 22(S5): 1-36. [Hungarian]

[3] Whelton SP, McEvoy JW, Shaw L, et al. Association of normal systolic blood pressure level with cardiovascular disease in the absence of risk factors. JAMA Cardiol. 2020; 5: 1011-1018.

[4] Kannel WB, Vasan RS, Levy D. Is the relation of systolic blood pressure to risk of cardiovascular disease continuous and graded, or are there critical values? Hypertension 2003; 42: 453-456. 
[5] Angeli F, Reboldi G, Verdecchia P. Hypertension and the J-curve phenomenon: implications for tight blood pressure control. Hypertens Res. 2013; 36: 109-111.

[6] Kékes E, Paksy A, Tóth K. The incidence of coronary artery disease in treated hypertension in the case of blood pressure categories. Hungarian Hypertension Registry 2011-2013-2015. [A koszoruér-betegség előfordulása kezelt hipertóniában a vérnyomásértékek függvényében. Magyar Hipertónia Regiszter 2011-2013-2015.] Cardiol Hung. 2020; 50: 38-45. [Hungarian]

[7] Reboussin DM, Carey RM, Whelton PK. Evidence supporting the blood pressure treatment goal of less than $130 / 80 \mathrm{~mm} \mathrm{Hg}$. Hypertension 2019; 73: 972-974.

[8] Egan BM, Kjeldsen SE, Grassi G, et al. The global burden of hypertension exceeds 1.4 billion people: should a systolic blood pressure target below 130 become the universal standard? J Hypertens. 2019; 37: 1148-1153.

[9] Wright JT Jr, Williamson JD, Whelton PK, et al. A randomized trial of intensive versus standard blood-pressure control. N Engl J Med. 2015; 373: 2103-2116.

[10] Fuchs FD, Whelton PK. High blood pressure and cardiovascular disease. Hypertension 2020; 75: 285-292.

[11] Vasan RS, Larson MG, Leip EP, et al. Impact of high-normal blood pressure on the risk of cardiovascular disease. $\mathrm{N}$ Engl J Med. 2001; 345: 1291-1297.

[12] He J, Whelton PK. Elevated systolic blood pressure and risk of cardiovascular and renal disease: overview of evidence from observational epidemiologic studies and randomized controlled trials. Am Heart J. 1999; 138: 211-219.

[13] Port S, Garfinkel A, Boyle N. There is a non-linear relationship between mortality and blood pressure. Eur Heart J. 2000; 21 : $1635-1638$

[14] Lewington S, Clarke R, Qizilbash N, et al., Prospective Studies Collaboration. Age-specific relevance of usual blood pressure to vascular mortality: a meta-analysis of individual data for one million adults in 61 prospective studies. Lancet 2002; 360: $1903-$ 1913

[15] Fuchs FD. Epidemiological evidence in essential of hypertension. In: Fuchs FD. (ed.) Essentials of hypertension. Part 1.1.1. Springer AG, Cham, 2018; pp. 3-8.

[16] Beckett NS, Peters R, Fletcher AE, et al. Treatment of hypertension in patients 80 years of age or older. N Engl J Med. 2008; 358: 1887-1898.

[17] Kaplan NM. Causes of death in untreated hypertension. In: Kaplan NM. (ed.) Clinical hypertension. Seventh edition. Williams \& Willkins, Chicago, IL, 1998; pp. 108-116.

[18] Tozawa M, Iseki K, Iseki C, et al. Blood pressure predicts risk of developing end-stage renal disease in men and women. Hypertension 2003; 41: 1341-1345.

[19] Rapsomaniki E, Timmis A, George J, et al. Blood pressure and incidence of twelve cardiovascular diseases: lifetime risks, healthy life-years lost, and age-specific associations in 1.25 million people. Lancet 2014; 383: 1899-1911.

[20] Panjrath GS, Chaudhari S, Messerli FH. The J-point phenomenon in aggressive therapy of hypertension: new insights. Curr Atheroscler Rep. 2012; 14: 124-129.

[21] Wan EY, Yu EY, Chin WY, et al. Association of blood pressure and risk of cardiovascular and chronic kidney disease in Hong Kong hypertensive patients. Hypertension 2019; 74: 331-340.

[22] Heinzl H, Kaider A. Gaining more flexibility in Cox proportional hazards regression models with cubic spline functions. Comput Methods Programs Biomed. 1997; 54: 201-208.

[23] Whelton PK, Muntner P. Potential implications of the systolic blood pressure intervention trial in Korea. J Am Coll Cardiol. 2016; 67: 2832-2834

[24] Williamson JD, Supiano MA, Applegate WB, et al. Intensive vs standard blood pressure control and cardiovascular disease outcomes in adults aged $\geq 75$ years: a randomized clinical trial. JAMA 2016; 315: 2673-2682.
[25] Ettehad D, Emdin CA, Kiran A, et al. Blood pressure lowering for prevention of cardiovascular disease and death: a systematic review and meta-analysis. Lancet 2016; 387: 957-967.

[26] Bundy JD, Li C, Stuchlik P, et al. Systolic blood pressure reduction and risk of cardiovascular disease and mortality: a systematic review and network metaanalysis. JAMA Cardiol. 2017; 2: 775781.

[27] Williamson JD, Pajewski NM, Auchus AP, et al. Effect of intensive vs standard blood pressure control on probable dementia: a randomized clinical trial. JAMA 2019; 321: 553-561.

[28] Nasrallah IM, Pajewski NM, Auchus AP, et al. Association of intensive versus standard blood pressure control with cerebral white matter lesions. JAMA 2019; 322: 524-534.

[29] Székács B, Kékes E. Hypertension and brain function. [Magasvérnyomás-betegség és agyi funkció.] Hyperton Nephrol. 2019; 23: 260-268. [Hungarian]

[30] Bild DE, Bluemke DA, Burke GL, et al. Multi-Ethnic Study of Atherosclerosis: objectives and design. Am J Epidemiol. 2002; 156: 871-881.

[31] Carr JJ, Nelson JC, Wong ND, et al. Calcified coronary artery plaque measurement with cardiac CT in population-based studies: standardized protocol of Multi-Ethnic Study of Atherosclerosis (MESA) and coronary artery risk development in young adults (CARDIA) study. Radiology 2005; 234: 35-43.

[32] Ungvari Z, Tarantini S, Donato AJ, et al. Mechanisms of vascular aging. Circ Res. 2018; 123: 849-867.

[33] Bruno RM, Nilsson PM, Engström G, et al. Early and supernormal vascular aging. Hypertension 2020; 76: 1616-1624.

[34] Blaha MJ, Mortensen MB, Kianoush S, et al. Coronary artery calcium scoring: is it time for a change in methodology? JACC Cardiovasc Imaging 2017; 10: 923-937.

[35] Laurent S, Boutouyrie P, Cunha PG, et al. Concept of extremes in vascular aging. From early vascular aging to supernormal vascular aging. Hypertension 2019; 74: 218-228.

[36] Vlachopoulos C, Terentes-Printzios D, Laurent S, et al. Association of estimated pulse wave velocity with survival: a secondary analysis of SPRINT. JAMA Netw Open 2019; 2: el912831

[37] Whelton PK, Carey RM, Aronow WS, et al. 2017 ACC/AHA/ AAPA/ABC/ACPM/AGS/APhA/ASH/ASPC/NMA/PCNA guideline for the prevention, detection, evaluation, and management of high blood pressure in adults: executive summary: a report of the American College of Cardiology/American Heart Association Task Force on Clinical Practice Guidelines. Hypertension 2018; 71: 1269-1324. [Erratum: Hypertension 2018; 71: el36-el39.] [Erratum: Hypertension 2018; 72: e33.]

[38] Williams B, Mancia G, Spiering W, et al. 2018 ESC/ESH Guidelines for the management of arterial hypertension: The Task Force for the management of arterial hypertension of the European Society of Cardiology and the European Society of Hypertension. J Hypertens. 2018; 36: 1953-2041. [Erratum: J Hypertens. 2019; 37: 226.]

[39] Kékes E, Vályi P. Similarities and differences of the most significant international guidelines for the treatment of hypertension. [Hasonlóságok és különbségek a hypertoniabetegség ellátásával foglalkozó legjelentősebb nemzetközi irányelvekben.] LAM 2020; 30: 407-417. [Hungarian]

[40] Tocci C, Presta V, Figliuzzi I, et al. Reclassification of hypertensive outpatients according to new US guidelines on high blood pressure. Am J Hypertens. 2019; 32: 77-88.

[41] Qaseem A, Wilt TJ, Rich R., et al., for the Clinical Guidelines Committee of the American College of Physicians and the Commission on Health of the Public and Science of the American Academy of Family Physicians. Pharmacologic treatment of hypertension in adults aged 60 years or older to higher versus lower blood pressure targets: a clinical practice guideline from the American College of Physicians and the American Academy of Family Physicians. Ann Intern Med. 2017; 166: 430-437. [Erratum: Ann Intern Med. 2018; 168: 530-532.] 
[42] Carey RM, Whelton PK. Evidence for the universal blood pressure goal of $<130 / 80 \mathrm{~mm} \mathrm{Hg}$ is strong. Hypertension 2020; 76: $1384-1390$

[43] Bangalore S, Toklu B, Gianos E., et al. optimal systolic blood pressure target after SPRINT: insights from a network metaanalysis of randomized trials. Am J Med. 2017; 130: 707-719.

[44] Mancia G. Target blood pressure values in the US and European guidelines. Are they truly similar? J Clin Hypertens. 2019; 21: 1602-1603.

[45] NCD Risk Factor Collaboration (NCD-RisC). Long-term and recent trends in hypertension awareness, treatment, and control in 12 high-income countries: an analysis of 123 nationally representative surveys. Lancet 2019; 394: 639-651.

[46] NCD Risk Factor Collaboration (NCD-RisC). Contributions of mean and shape of blood pressure distribution to worldwide trends and variations in raised blood pressure: a pooled analysis of 1018 population-based measurement studies with 88.6 million participants. Int J Epidemiol. 2018; 47: 872-883i.

[47] Cené CW, Halladay JR, Gizlice Z, et al. A multicomponent quality improvement intervention to improve blood pressure and reduce racial disparities in rural primary care practices. J Clin Hypertens (Greenwich). 2017; 19: 351-360.

[48] Sadeghi C, Khan HA, Gudleski G, et al. Multifaceted strategies to improve blood pressure control in a primary care clinic: a quality improvement project. Int J Cardiol Hypertens. 2020; 7: 100060.

[49] Szegedi J, Kékes E, Kiss I. Hungarian Hypertension Registry. Different methods and effects of increasing physician-patient cooperation on target blood pressure. $[\mathrm{Az}$ orvos-beteg együttmúködés növelésének különböző módszerei és hatása a célvér- nyomásra a Magyar Hypertonia Regiszter adatai alapján.] Hyperton Nephrol. 2019; 23: 157-166. [Hungarian]

[50] Sagner M, McNeil A, Puska P. The 4P health spectrum - a predictive, preventive, persolanized and participatory continuum for promoting healthspan. Prog Cardiovasc Dis. 2017; 59: 506521.

[51] Vályi P. From healthcare across health affair to "whole-ness" affair. [Az egészségügytől az „,egészség-ügy”-ön át a „teljességügy"-ig.] Hyperton Nephrol. 2017; 21: 262-269. [Hungarian]

[52] Vályi P. From disease-centric to P4 medicine. A way to implement a care system that focuses on human health. [A betegségközpontúságtól a P4 orvoslásig. Út az ember egészségét a középpontba állító ellátórendszer megvalósításához.] LAM 2019; 29: 102-103. [Hungarian]

[53] Hungarian Parliament. Act No. CLIV of 1997 on health care. [Magyar Országgyúlés. 1997. évi CLIV. törvény az egészség ügyről.] Available from: www.net.jogtar.hu. [Hungarian]

[54] Decree No. 51/1997 (18. XII.) of the Ministry of Welfare on health services for the prevention and early detection of diseases available within the framework of compulsory health insurance and on the certification of screening tests. [51/1997. (XII. 18.) NM rendelet a kötelező egészségbiztosítás keretében igénybe vehető betegségek megelőzését és korai felismerését szolgáló egészségügyi szolgáltatásokról és a szűrővizsgálatok igazolásáról.] Available from: www. net.jogtar.hu . [Hungarian]

(Kékes Ede dr., Pécs, Ifjúság útja 13., 7624 e-mail: kekesede@gmail.com)

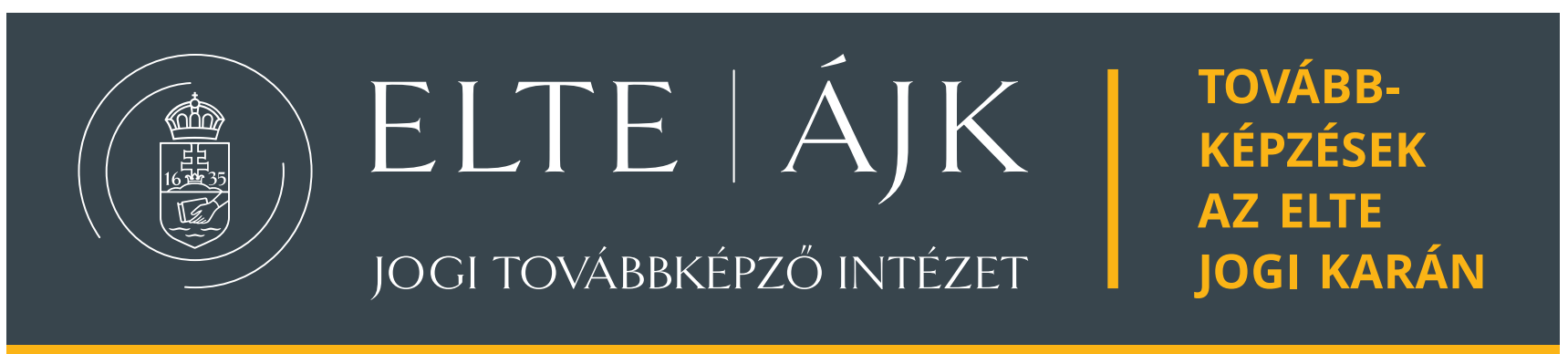

Helyszín:

ELTE Főépület,

1053 Budapest,

Egyetem tér $1-3$.

További információk:

https://jotoki.elte.hu/

Jelentkezési határidő:

2021. augusztus 31.

\section{Egészségügyi szakjogász képzés}

- átfogó elméleti és gyakorlati jogi tudást biztosít az egészségügy területén

- hatékony segítség az egészségügyi intézményműködtetés átlátásában, az egészségpolitikai döntéshozatal, az állami és a magán-egészségbiztosítás, egészségügyi ellátás jogalkotás komplex működési folyamatainak megértésében

- akiknek ajánljuk: egészségügyi joggal foglalkozó bírók, hatósági tisztviselők, ügyvédek, egészségügyi intézményi jogtanácsosok, gyógyszerforgalmazó cégek, egészségügyi beszállítók

\section{Jogi szakokleveles orvos- és egészségůgyi szakember képzés}

• hatékony jogi, igazgatási problémakezelés az egészségügy működése és működtetése során - a képzés fontos feladata, hogy kialakítsa a betegellátással kapcsolatos konfliktushelyzetek felismerésének és megfelelő kezelésének, a betegjogok gyakorlati érvényre juttatásának képességét

- akiknek ajánljuk: orvosok, fogorvosok, gyógyszerészek

További képzéseink az egészségügyben dolgozók számára: • Adatbiztonsági és adatvédelmi szakjogász • Munkajogi szakjogász • Adójogi szakjogász

A cikk a Creative Commons Attribution 4.0 International License (https://creativecommons.org/licenses/by/4.0/) feltételei szerint publikált Open Access közlemény, melynek szellemében a cikk bármilyen médiumban szabadon felhasználható, megosztható és újraközölhetö, feltéve, hogy az eredeti szerző és a közlés helye, illetve a CC License linkje és az esetlegesen végrehajtott módosítások feltüntetésre kerülnek. (SID_1) 